\title{
ISOTOPES, INC. RADIOCARBON MEASUREMENTS III
}

\author{
MILTON A. TRAUTMAN \\ Isotopes, Incorporated, Westwood, New Jersey \\ INTRODUCTION
}

The following list presents dates obtained on a fraction of the total num. ber of measurements made during the years 1961 and 1962 and measurements made previously for which sample data has been recently received. The results which do not appear are withheld pending additional information, or at the request of our clients.

Procedures employed in sample pretreatment, preparation of $\mathrm{CO}_{2}$ and method of counting remain unchanged as are our methods of age calculation. In addition to the two counters previously described, (Isotopes, Inc. I, II), a third counter is now in use. The volume of the third counter is slightly over two liters. Background is 9.4 counts $/ \mathrm{min}$. and $\mathrm{A}_{\mathrm{ox}} \times 0.95$ is 26.1 counts $/ \mathrm{min}$. Except for minor alterations, the comments on the $\mathrm{C}^{14}$ ages, information concerning the sample site, etc., are provided by the persons submitting samples.

\section{ACKNOWLEDGMENTS}

It is recognized that data obtained at Isotopes, Inc. remain the sole property of our clients. Nevertheless, we encourage our clients to submit these descriptions for publication and we wish to acknowledge the cooperation of all personnel mentioned in this list. In addition, we are indebted to Jerry M. Bonicos of Isotopes, Inc. for technical assistance in the laboratory.

\section{GEOLOGIC SAMPLES}

\section{A. Alaska}

\section{Copper River Basin, Alaska series}

Samples from Copper River Basin area, Alaska. Samples were collected by members of the staff and subm. in 1961 by W. E. Davies, U. S. Geol. Survey, Washington, D. C.

\section{I-267. Gulkana River, Alaska}

Wood from river bluff exposure along E side Gulkana River $\left(63^{\circ} 23^{\prime} \mathrm{N}\right.$ Lat, $145^{\circ} 22^{\prime} \mathrm{W}$ Long), near mi 135.4, Richardson Highway. Wood present in laminated sand and silt unit overlain by $10 \mathrm{ft}$ of lacustrine diamicton, $12 \mathrm{ft}$ of poorly stratified silt with numerous pebble-sized phenoclasts, and 2 to $3 \mathrm{ft}$ of windblown silt and fine sand at the surface. Sampled unit is underlain by sand and gravel. Coll. 1958 by O. J. Ferrians, Jr. and H. R. Schmoll. Comment (W.E.D.) : sample dates the time of transition from a fluvial to a lacustrine environment of deposition during the initial phase of last major glaciation in area.

\section{I-268. Indian River, Alaska}

$$
\begin{array}{r}
1750 \\
\text { A.D. } 200
\end{array}
$$

Wood from cut-bank $16 \mathrm{ft}$ high on $\mathrm{W}$ side Indian Creek, $2 \mathrm{mi} \mathrm{W}$ of its confluence with the Copper River (62 $41^{\prime} \mathrm{N}$ Lat, $144^{\circ} 26^{\prime} \mathrm{W}$ Long). Wood 
present $6 \mathrm{in}$. above base of $13 \mathrm{ft}$ of organic silt and sand at surface. Organic silt and sand underlain by $3 \mathrm{ft}$ medium to coarse gravel. Coll. 1956 by $\mathrm{O}$. J. Ferrians, Jr., and H. R. Schmoll, Comment (W.E.D.) : dates time when small alluvial fan was actively forming along margin of Indian Creek valley.

\section{I-270. Ahtell Creek, Alaska}

$$
1260 \pm 100
$$

\section{A.D. 690}

Peat and organic silt from small cut along trail on intermediate terrace on $\mathrm{N}$ side of Ahtell Creek, ca. $1.5 \mathrm{mi}$ from the Glenn Highway $\left(62^{\circ} 44^{\prime} \mathrm{N}\right.$ Lat, $143^{\circ} 59^{\prime}$ W Long), Alaska. Taken from top of 1.5 in. layer of peat, organic silt and fine sand which overlies gravel and is overlain by sand. Coll. 1960 by H. R. Schmoll and R. H. Bennett; subm. 1961 by H. R. Schmoll. Comment (H.R.S.) : date marks a time toward close of deposition of materials in this terrace subsequent to which terrace was cut and the low-terrace material deposited.

\section{I-269. Drop Creek, Alaska}

Organic silt from small exposure on NE hank Drop Creek (62 $35^{\prime} \mathrm{N}$ Lat, $143^{\circ} 50^{\prime} \mathrm{W}$ Long), Nabesna C.6 quadrangle, Alaska. Organic silt overlies till, and is overlain by interbedded onganic silt and colluvial diamicton. Coll. 1960 by H. R. Schmoll and R. H. Bennett; subm. 1961 by H. R. Schmoll. Comment (H.R.S.) : date is minimum for glaciation of area and is consistent with other dates in adjacent areas.

\section{I-364. Mentasta Basin, Alaska}

Wood from thin layer $6 \mathrm{ft}$ below top of $80 \mathrm{ft}$ road cut at mi 77, Tok Cutoff of Glenn Highway ( $62^{\circ} 32^{\prime}$ N Lat, $143^{\circ} 40^{\prime} \mathrm{W}$ Long), Nabesna D.6 quadrangle, Alaska. Stratigraphic section includes $30 \mathrm{ft}$ of silt and fine sand overlain by $36 \mathrm{ft}$ of sand, all probably of glaciolacustrine origin. Coll. 1961 by H. R. Schmoll and R. H. Bennett; subm. 1961 by H. R. Schmoll. Comment (H.R.S.) : sample postdates incursion at Wrangell Mountain glaciers into the Mentasta Basin area, as well as most of subsequent glaciolacustrine deposition with concomitant damming ice in vicinity of Mentasta Lake from Alaska Range. Copper River Basin prohably was not filled with glacier ice after this time.

\section{I-271. Klutina River, Alaska}

Wood from tree limb exposed in middle of till section of 50 -ft river-bluff section, $N$ side Klutina River, $0 . \overline{\mathrm{mi}} \mathrm{W}$ of its mouth at Copper Center $\left(61^{\circ}\right.$ $57^{\prime} 30^{\prime \prime} \mathrm{N}$ Lat, $145^{\circ} 19^{\prime} \mathrm{W}$ Long), Alaska. Till is overlain by $15 \mathrm{ft}$ of terrace gravel and underlain by fluvial sand and gravel, lacustrine silt. and till. Coll. 1955 by D. R. Nichols. Comment (W.E.D.) : date is minimum for tili (Chetaslina glaciation: Nichols, in preparation) now thought to be middle or early Pleistocene.

\section{I.272. Chitina, Alaska}

$$
\begin{aligned}
& 8480 \pm 150 \\
& 6530 \text { в.с. }
\end{aligned}
$$

Compressed wood (spruce?) from bank of small unnamed tributary to Copper River, $2 \mathrm{mi}$ S of Chitina $\left(61^{\circ} 29^{\prime} \mathrm{N}\right.$ Lat, $144^{\circ} 28^{\prime} \mathrm{W}$ Long), Alaska. 
From oxidized sand overlain by silty peat with numerous woody zones and underlain by fluvial sand and gravel. Entire section was permafrost. Coll. 1956 by D. R. Nichols. Comment (W.E.D.) : dates cessation of rapid alluviation following drainage of large proglacial lake after retreat of $\mathrm{Mt}$. Drum glaciers in late Pleistocene time.

\section{I-438. Harbor Point, Alaska}

\section{Modern}

Wood (Alnus) from stump rooted in surface of till $20 \mathrm{ft}$ above mean sealevel, $1000 \mathrm{ft}$ from high-tide shoreline at Harbor Point $\left(58^{\circ} 36^{\prime} \mathrm{N}\right.$ Lat, $137^{\circ}$ $39^{\prime}$ W Long), on S side of entrance to Lituya Bay, Alaska. Sample was formerly buried in surficial peat and soil, removed by the giant wave in Lituya Bay July 9, 1958. Coll. 1958 and subm. 1959 by D. J. Miller. Comment (D.J.M.) : the stump was believed immediately to postdate last retreat of ice from the end moraine forming the constricted entrance to Lituya Bay. W-800, $6060 \pm 200$ (USGS V), is from an ice-sheared stump at base of the surficial till; the two samples, therefore, are interpreted as bracketing the last advance of ice to the mouth of Lituya Bay, and retreat from that stand.

\section{I-646. Ruby Creek, Alaska \\ $5900 \pm 250$ 3950 в.с.}

Wood from root of buried white spruce from terrace on $\mathrm{E}$ side of Delta River along Richardson Highway, in Central Alaska Range, where Ruby Creek crosses highway $\left(63^{\circ} 38^{\prime} \mathrm{N}\right.$ Lat, $145^{\circ} 53^{\prime} \mathrm{W}$ Long). Taken $16.8 \mathrm{ft}$ below surface in loess, $0.8 \mathrm{ft}$ above gravel underlying terrace. Coll. and subm. $1962 \mathrm{by}$ T. L. Péwé, Univ. of Alaska, College, Alaska. Comment (T.L.P.) : date marks beginning of loess deposition on late Pleistocene terrace and is minimum for Late Donnelly glaciation (Péwé, 1953).

\section{I-647. Ruby Creek, Alaska}

$2300 \pm 180$ 350 в.C.

Peat from 5 in. above top of gravel terrace in peat layer associated with artifacts in loess, E side of Delta River where Richardson Highway crosses Ruby Creek, Alaska (63 $38^{\prime}$ N Lat, $145^{\circ} 53^{\prime}$ W Long). Coll. 1962 by T. L. Péwé, R. D. Reger, and Gerard Bond; subm. 1962 by T. L. Péwé. Comment (T.L.P.) : site is first archaeological site in interior Alaska to be dated by $\mathrm{C}^{14}$ (Péwé, 1953).

\section{I-648. Gulkana Glacier, Alaska}

$800 \pm 125$

Peat from gravel terrace on W side Gulkana Glacier $\left(63^{\circ} 14^{\prime} \mathrm{N}\right.$ Lat, $145^{\circ}$ $29^{\prime}$ W Long), central part of Alaska Range, Alaska. From buried peat layer ca. $7 \mathrm{~mm}$ thick, $4 \mathrm{ft}$ from base of gravel terrace, $10 \mathrm{ft}$ below surface. Coll. and subm. 1962 by T. L. Péwé. Comment (T.L.P.) : date is minimum for a recent advance or ice position (Sellmann, 1962).

\section{I-206. Anaktuvuk Pass, Alaska}

$4750 \pm 110$

2800 в.c.

Peat from beneath 10 to 12 in. unfrozen, mineral tundra soil in silty drift of Echooka age, adjacent to NE end of Summit Lake, Anaktuvuk Pass $\left(68^{\circ} 9^{\prime}\right.$ $\mathrm{N}$ Lat, $151^{\circ} 43^{\prime} \mathrm{W}$ Long), Alaska. Sample was frozen and consisted of a layer 
2 to 4 in. thick of fibrous plant remains virtually free of mineral particles. Cottongrass-tussock vegetation was unbroken at sample site, indicating relative stability of the surface and no recent frost action (Douglas and Tedrow, 1960). Coll. 1959 and subm. 1961 by Jerry Brown, Rutgers Univ., New Brunswick, New Jersey. Comment (J.B.) : two minimum dates are reported by Porter (1962) from samples in perennially frozen lacustrine silt in an Eskimo cellar (Mackay, 1961) on W side of Summit Lake $(6260 \pm 160$, Y.770, Yale VI, and 724.1 \pm 95, Y-1082, Yale VIII). Present sample agrees with the proposed chronology and suggests burial of peat, possibly by frost churning during the Hypsithermal interval (Porter, 1962). Sample pretreated with $0.5 \% \mathrm{NaOH}$ and $1 \% \mathrm{HCl}$.

\section{I-207. Okpilak River, Alaska}

$175 \pm 75$

Partially humified organic matter of A. Horizon, maximum 5 in. thick, from podzol-like soil several hundred yards SW of W Okpilak Lake $\left(69^{\circ} 25^{\prime}\right.$ N Lat, 144 ${ }^{\circ}$ W Long), Alaska. Coll. 1959 and subm. 1961 by Jerry Brown. Comment (J.B.): soil morphology in the surrounding pit suggested frost churning prior to or coincident with formation of the underlying $A_{1}$ horizon (Brown, 1962). The relatively young age, although average for the horizon, indicates active soil formative process in this arctic region, as compared to the age of an $A_{1}$ horizon at Point Harrow, Alaska, $3000 \pm 130$ (L-400A, Lamont V).

\section{B. Eastern United States}

\section{I-368. Laurel Creek Cave}

$$
900 \pm 200
$$

Snail shells from sand layer $4 \mathrm{ft}$ below top of cave-earth fill $9 \mathrm{ft}$ thick, capped by flowstone 2 to 3 in. thick, Laurel Creek Cave, Monroe, West Virginia ( $37^{\circ} 33^{\prime} 32^{\prime \prime} \mathrm{N}$ Lat, $80^{\circ}$ B9' 56" W Long). Coll. 1958 and subm. 1961 by W. E. Davies. Comment: dates middle part of cave fill and is minimum for flowstone.

\section{I-610. Sefton Farm}

$\mathbf{2 0 , 0 0 0} \pm 500$ 18,050 в.с.

Wood from calcareous, orgnic-rich silt, at Sefton Farm $\left(39^{\circ} 35^{\prime} \mathrm{N}\right.$ Lat, $85^{\circ} 7^{\prime} 32^{\prime \prime} \mathrm{W}$ Long), $12 \mathrm{mi} \mathrm{E}$ of Nulltown, Fayette County, Indiana. Silt is underlain and overlain by calaareous till. Coll. and subm. 1962 by A. M. Gooding. Earlham College, Richmond, Indiana. Comment (A.M.G.) : wood is from a post-Sangamon interstadtal deposit (Gooding, in press).

\section{I-586. Wells Mastodon site, Indiana}

$12,000 \pm 450$ 10,050 в.с.

Wood from $90 \mathrm{in}$. level in excavation for the Wells Mastodon, SE $1 / 4 \mathrm{Sec}$. 17, 'T. 30 N., R. 2 E (41 $4^{\circ}$ ' N Lat, $86^{\circ} 15^{\prime}$ W Long), ca. 5 mi W of Rochester, Indiana. Sample is from marl overlain by organic sand and peat, and lies just below level of most of the mastodon remains. Coll. and subm. by A. M. Gooding. Comment (A.M.G.): site is in broad area of valley-train and outwash between the Maxinkukee and Packenton moraines. Pollen profile for site suggests mixing of marl by the mastodon, but overlying peat appear not to have 
been disturbed. A rather rapid change from dominantly coniferous pollen below, to dominantly deciduous pollen above occurs at base of peat. A similar change was dated in a pollen profile near Richmond, Indiana at ca. 11,000 B.P. (Ogden, 1963; Kapp, 1963).

\section{I-587. American Aggregates, Indiana}

Wood from railroad cut at American Aggregates gravel quarry $\left(39^{\circ} 50^{\prime}\right.$ $30^{\prime \prime} \mathrm{N}$ Lat, $84^{\circ} 49^{\prime} 30^{\prime \prime} \mathrm{W}$ Long), at NE edge of Richmond, Indiana. Taken 6 in. below top of calcareous till. Coll. and subm. by A. M. Gooding. Comment (A.M.G.) : organic silt and till beneath it are believed to be post-Sangamon in age (Gooding, 1963; Kapp, 1963). L-478B, >40,500 (Lamont VII), is from same deposit.

\section{I-611. Cummins Farm}

\section{$>40,000$}

Wood from creek-bank exposure on Cummins Farm $\left(39^{\circ} 40^{\prime} \mathrm{N}\right.$ Lat, $85^{\circ}$ $15^{\prime} 30^{\prime \prime}$ W Long), Fayette County, Indiana. Sample appeared to be part of stump in situ on top of intact paleosol, and was surrounded by calcareous rock flour and overlain by calcareous till. Coll. and subm. 1962 by A. M. Gooding. Comment (A.M.G.) : paleosol is interpreted to be of Sangamon age (Gooding, in press).

\section{Canada}

\section{I-428. Gilman Glacier, Canada}

$$
965 \pm 75
$$

Moss from surface of sand, gravel and weathered sliderock near margin of a small ice dome on E side of Gilman Glacier. Elesmere Island $\left(82^{\circ} 11^{\prime} \mathrm{N}\right.$ Lat, $70^{\circ} 56^{\prime} \mathrm{W}$ Long). Sample, from alt $3800 \mathrm{ft}$ is known to have been exposed by recession of ice dome during summer of 1960 (Hattersley-Smith, G. et al., 1961). Coll. and subm. 1961 by G. Hattersley-Smith, Defence Res. Board, Ottawa, Canada. Comment: locality is close to altitude limit of present moss growth. Age is consistent with belief that ice cover was no more extensive and climate no more severe 1000 yr ago than now.

\section{I-462. Drynoch Slide, Canada}

$3175 \pm 150$

1225 в.c.

Wood from failure zone beneath Drynoch Slide, on Transcanada Highway, $\mathrm{E}$ hank of Thompson River $4 \mathrm{mi} \mathrm{SW}$ of Spences Bridge, British Columbia $\left(50^{\circ}\right.$ $17^{\prime} \mathrm{N}$ Lat, $121^{\circ} 18^{\prime} \mathrm{W}$ Long). Portion of tree trunk beneath slide and covering vegetation in situ. Coll. and subm. 1961 by C. O. Brawner, Dept. of Highways, Victoria, British Columbia, Canada. Comment: wood is thought to date commencement of the slide (Drysdale, C. W., 1914).

\section{Hekla Sund series, Greenland}

$$
\text { E. Greenland }
$$

Shell samples from marine deposits and terrace in the Hekla Sund area, NE Greenland. Coll. 1960 by W. E. Davies and D. B. Krinsley; subm. 1961 by W. E. Davies.

\section{I-365. Rivieradal, $68 \mathrm{ft}$}

Shells (Hiatella arctica and Mya truncata) imbedded in marine silt under- 
lying marine terrace at alt $68 \mathrm{ft}$ on S side of Rivierdal $\left(80^{\circ} 3^{\prime} \mathrm{N} \mathrm{Lat}, 20^{\circ} 40^{\prime}\right.$ W Long). Comment (W.E.D.) : compares with I(USGS) -367 and I(USGS) 366 at Saefaxi Elv, 4 mi N.

\section{I-366. Saefaxi Elv, $130 \mathrm{ft}$}

$6900 \pm 150$

Shells (Hiatella arctica and Mya truncata) from upper 4 in. of marine silt underlying terrace at alt $130 \mathrm{ft}$ on $\mathrm{N}$ side Saefaxi Elv $\left(80^{\circ} 6^{\prime} \mathrm{N}\right.$ Lat, $20^{\circ} 40^{\prime} \mathrm{W}$ Long). Terrace flanks morainal ridges. Comment (W.E.D.): agrees with I(USGS) - 367 from S side of river. Also compares with I(USGS) -370, 6700 \pm 150 , from Ingolf Fjord, $30 \mathrm{mi} \mathrm{N}$ at alt $190 \mathrm{ft}$.

\section{I-367. Saefaxi Elv, 125 to 145 ft}

$$
\begin{aligned}
& 6800 \pm 150 \\
& 4850 \text { в.с. }
\end{aligned}
$$

Shells (Hiatella arctica and Mya truncata) from upper $4 \mathrm{in}$. of marine silt underlying terrace at 125 to $145 \mathrm{ft}$ and on $\mathrm{S}$ side Saefaxi Elv $\left(80^{\circ} 6^{\prime} \mathrm{N}\right.$ Lat, $20^{\circ} 40^{\prime} \mathrm{W}$ Long). Comment (W.E.D.) : age is comparable to I(USGS) -366 which is from $\mathrm{N}$ side Saefaxi Elv.

\section{I-369. Saefaxi Elv, $23 \mathrm{ft}$}

$3375 \pm 125$

1450 в.c.

Shells (Mya truncata) from upper $6 \mathrm{in}$. of marine silty clay at alt $23 \mathrm{ft}$ at mouth of Saefaxi Elv ( $80^{\circ} 6^{\prime} \mathrm{N}$ Lat, $20^{\circ} 40^{\prime} \mathrm{W}$ Long).

\section{I-370. Ingolf Fjord}

$6700 \pm 150$

Shells (Hiatella arctica and Mya truncata) from upper 4 in. of marine terrace at alt $190 \mathrm{ft}$ at head of $\mathrm{S}$ arm of Ingolf Fjord $\left(80^{\circ} 28^{\prime} \mathrm{N}\right.$ Lat, $20^{\circ} 45^{\prime}$ W Long). Comment (W.E.D.) : age compares with I(USGS)-367 and I (USGS) -366 from $30 \mathrm{mi} \mathrm{S.}$

\section{Mesters Vig series, Greenland}

Various samples from Mesters Vig outwash plain $\left(72^{\circ} \mathrm{N}\right.$ Lat, $24^{\circ} \mathrm{W}$ Long), NE Greenland. Coll. 1961 by Fred Pessl and N. P. Lasca, Univ. of Michigan, Ann Arbor; subm. 1961 by Fred Pessl (Pessl, 1962).

\section{I (UM) -429. Kong Oscars Fjord}

Baleen from sand and gravel in an emerged beach at alt ca. $50 \mathrm{~m}$ deposit, $\mathrm{S}$ shore Kong Oscars Fjord, ca. $1 \mathrm{~km} \mathrm{SE}$ of mouth of Mesters Vig. Comment (F.P.) : date agrees with those obtained from shell and wood collected at similar altitudes nearby (Washburn and Stuiver, 1962).

\section{Oske River series}

Shell samples from SW side of mouth of Oske River.

\section{I-432. Oske River 1}

Shells (Hiatella arctica) from emerged delta remnant at alt ca. $40 \mathrm{~m}$. Comment (F.P.) : date agrees with dates of other samples collected in vicinity (Washburn and Stuiver, 1962). 


\section{I-430. Oske River 2}

Shells (Mya truncata, Hiatella arctica), in growth position, from emerged delta remnant, alt ca. 53 m. Comment (F.P.) : date agrees with baleen (I-429, this list) from similar altitude in same vicinity, and with data published by Washburn and Stuiver (1962).

\section{I-431. Oske River 3}

$5500 \pm 175$ 3550 в.c.

Shells (Macoma calcarea, Astarte, pulchella, Clincardium ciliatum) from rim of a breched pingo in stoney clay, punched up through overlying outwash gravels, at alt ca. $13 \mathrm{~m}$. Comment (F.P.) : date not relevant to postglacial isostatic adjustment data because of development of the pingo; however it is maximum for deposition of the outwash gravel.

\section{I-556. Mahoma Lake, Uganda}

$$
\text { F. Africa }
$$

$14,700 \pm 290$

12,750 в.с.

Gyttja from Mahoma Lake $\left(0^{\circ} 21^{\prime} \mathrm{N}\right.$ Lat, $29^{\circ} 58^{\prime} \mathrm{E}$ Long), alt $3000 \mathrm{~m}$, the lowest glacial lake in the Ruwenzori Range. Sample from 5.2 to $5.4 \mathrm{~m}$ depth in lake sediment at a station in $0.5 \mathrm{~m}$ of water. Coll. 1960 and subm. 1962 by D. A. Livingstone, Duke Univ., Durham, North Carolina. Comment (D.A.L.) : date is a minimum for and probably close to true age of glacial retreat from the lowest valley moraines. This is first known direct dating of any glacial event in equatorial Africa, and indicates that retreat from the last glacial maximum was synchronous with that in the temperate zone (Livingstone, 1962).

\section{ARCHAEOLOGIC SAMPLES}

\section{A. Eastern United States}

\section{I-424. O'Neil Farm, New York}

Charcoal from hearth at 31 to 39 in. below surface in Sec. E 20520, Feature 4, on the E. J. O'Neil Farm ( $43^{\circ} 04^{\prime} 48^{\prime \prime}$ N Lat, $76^{\circ} 35^{\prime} 09^{\prime \prime}$ W Long), $2.25 \mathrm{mi}$ NW of Weedsport, Cayuga County, New York. Feature 4 occupies a shallow depression in top of the lowest of three strata, each with different cultural complex. Hearth occurred at top of Late Archaic horizon, in immediate contact with major cultural stratum of site which pertained to Transitional period, Susquehanna Broad point complex. Coll. and subm. 1961 by W. A. Ritchie, N. Y. State Mus. and Sci. Service, Albany, N. Y. Comment (W.A.R.) : appears to date terminal Archaic occupation at this site, a late manifestation of the Brewerton focus.

\section{I-425. Bates Site, New York}

$825 \pm 100$

\section{A.D. 1125}

Charcoal from storage pit (Feature 89), 35 in. deep, Bates Site $\left(42^{\circ} 17^{\prime}\right.$ $50^{\prime \prime}$ N Lat, $75^{\circ} 47^{\prime} 42^{\prime \prime}$ W Long), $2.25 \mathrm{mi}$ S of Greene, Chenango County, New York. From lower level beneath a shell layer. Site is small village of late Woodland Owasco culture. Coll. 1958 and subm. 1961 by W. A. Ritchie. Comment 
(W.A.R.) : charcoal from Feature 22, a similar storage pit at this site, has been dated at $660 \pm 200$ (M-762, Michigan IV). This date (I-425), is closer to the expected age.

\section{Russell Cave Series, Alabama}

Charcoal from within Russell Cave ( $34^{\circ} 58^{\prime} \mathrm{N}$ Lat, $85^{\circ} 48^{\prime} 32^{\prime \prime}$ W Long), Doran Cove, Jackson County, Alabama. The cave has been excavated extensively (Miller, 1958). Coll. and subm. by C. F. Miller, Smithsonian Inst., Washington, D. C.

\section{I-399. Russell Cave, 1 ft}

Charcoal from fire burned area $1 \mathrm{ft}$ beneath present cave floor. Cultural period attributed to Middle Mississippi evolving into Chickamauga Cherokee. Comment (C.F.M.) : date agrees with terminal Woodland period and emergence of the middle Mississippi period.

\section{I-396. Russell Cave, 2.0 ft}

$8350 \pm 180$

Charcoal from $2.0 \mathrm{ft}$ beneath present floor. Cultural period attributed to Early Archaic from Transitional of Paleo-Indian. Comment (C.F.M.) : date agrees with series dated at Univ. of Michigan (M-845, 846, 847, Michigan VI).

\section{I-398. Russell Cave, 6.5 ft}

Charcoal from large hearth at $6.5 \mathrm{ft}$ level. Comment (C.F.M.) : date agrees with series from various cultural levels (Michigan VI).

\section{I-397. Russell Cave, $10.0 \mathrm{ft}$}

Charcol from heart with cultural material of Early Archaic period (Michigan VI).

\section{I-480. Morris Site, F51, Kentucky $\quad 475 \pm 90$

Charred wood from firepit located in a wall trench house pattern, Feature 51, Structure 10, 2.4 ft deep at Morris Site, K $49\left(37^{\circ} 17^{\prime} \mathrm{N}\right.$ Lat, $87^{\circ} 35^{\prime} \mathrm{W}$ Long), Hopkins County, Kentucky. Site is $1.5 \mathrm{mi} \mathrm{SW}$ of junction of Sugar Creek with Clear Creek, a tributary of the Tradewater River, $5 \mathrm{mi}$ SW of Madisonville, Kentucky. Coll. 1941 by G. A. Jackson, Univ. of Kentucky, Lexington; subm. 1962 by D. W. Schwartz and M. A. Rolingson, Univ. of Kentucky. Comment (D.W.S., M.A.R.) : material associated with sample is Mississippian. Sample dates first of two building periods at site while I-481 (this list) dates the latter building period. The first period is characterized by construction of wall-trench house patterns and a wall-trench stockade pattern.

\section{I-481. Morris Site, F 16, Kentucky}

$\mathbf{2 7 0} \pm \mathbf{8 0}$

\section{A.D.1680}

Charred wood from deep firepit centrally located in an individual posthouse pattern, Feature 16, Structure 3, $3 \mathrm{ft}$ below surface at the Morris Site, HK $49\left(37^{\circ} 17^{\prime} \mathrm{N}\right.$ Lat, 87 $35^{\prime} \mathrm{W}$ Long), Hopkins County, Kentucky. Coll. 1941 by G. A. Jackson; subm. 1962 by D. W. Schwartz and M. R. Rolingson. 
Comment (D.W.S., M.A.R.) : material with sample is Mississippian. Sample dates from latter of two building periods while I-480, (475 \pm 90 , this list) dates the first period. The later period is characterized by the construction of individual post-house patterns and an individual post-stockade pattern.

\section{I-479. Roach Site, Kentucky}

\section{A.D. 1540}

$410 \pm 85$

Charred wood from SW corner of a wall trench pit house, from $2.5 \mathrm{ft}$ below surface at the Roach Site $\left(36^{\circ} 50^{\prime} \mathrm{N}\right.$ Lat, $88^{\circ} 8^{\prime} \mathrm{W}$ Long $)$, Triss County, Kentucky. This site is located $.25 \mathrm{mi} \mathrm{E}$ of the Tennessee River on the $\mathrm{N}$ bank of Ewes Branch, .75 mi upstream from entrance of Jonathan Creek into the Tennessee River. Coll. 1941 by James Greenacre, Univ. of Kentucky, Lexington; subm. 1962 by D. W. Schwartz and M. A. Rolingson. Comment (D.W.S., M.A.R.) : material in association with sample is Mississippian. Pottery associated with the house pattern included a Neeley's Ferry Plain globular jar.

\section{I-477. Goheen village, Kentucky}

$350 \pm 85$

Charred wood from SW corner of pit house, Feature 9 at Goheen village Site $\left(47^{\circ} 40^{\prime} \mathrm{N}\right.$ Lat, $88^{\circ} 8^{\prime} \mathrm{W}$ Long), Marshall County, Kentucky. Site is on W bank of Tennessee River, $1.5 \mathrm{mi} \mathrm{N}$ of entrance to Jonathan Creek into the Tennessee River. Structure originated in Zone A, and extended into Zone B. Sample is from Zone B. Coll. 1941 by Harold Dahms, Univ. of Kentucky, Lexington; subm. 1962 by D. W. Schwartz and M. A. Rolingson. Comment (D.W.S., M.A.R.) : material associated with sample is Mississippian.

\section{I-478. Tinsley Hill village, Kentucky}

$300 \pm 80$

\section{A.D. 1650}

Charred wood from center post of a wall-trench structure at depth of 37 $\mathrm{cm}$ at Tinsley Hill village (37 $7^{\circ} 1^{\prime} \mathrm{N}$ Lat, $88^{\circ} 3^{\prime} \mathrm{W}$ Long), Lyon County, Ken tucky. Site is on E bank Cumberland River, 1.8 mi SE of the Kentucky State Prison in Eddyville, and $0.6 \mathrm{mi}$ downstream from mouth of Eddy Creek. Coll. 1960 by L. H. Hanson, Jr., Univ. of Kentucky, Lexington; subm. 1962 by D. W. Schwartz and M. A. Rolingson. Comment (D.W.S., M.A.R.) : material associated with sample is Mississippian. The site lies at the foot of the bluff where the Tinsley Hill stone grove cemetery, dated at $570 \pm 150$ (M-1150, unpublished, is located (Schwartz, 1961).

\section{Missouri Basin}

\section{B. Central United States and Great Plains}

The following series of samples were submitted during late 1961 and early 1962 by R. W. Neuman, Smithsonian Inst., Lincoln, Nebraska, as part of the Missouri Basin chronology program. This program is part of a broad study of the archaeological history of the people and cultures in the Missouri Basin.

\section{Side Hill Mound series, South Dakota}

Samples from Mound 1, Side Hill mound site $\left(44^{\circ} 2^{\prime} 10^{\prime \prime} \mathrm{N}\right.$ Lat, $99^{\circ} 22^{\prime}$ 55" W Long), Buffalo County, South Dakota. Coll. and subm. 1961 by R. W. Neuman. 


\section{I-448. Side Hill Mound Site, Feature 1}

Charcoal bone (human) from 1.5 to $20 \mathrm{ft}$ depth in Feature 1. Comment (R.W.N.) : dates cremation in Mound 1 and supplies date for Truman Plain Rim pottery (Neuman, 1962).

\section{I-446. Side Hill Mound Site, Feature 2}

Charcoal from subfloor pit, Feature 2. Comment (R.W.N.) : provides date for burial at Mound 1 (Neuman, 1962).

\section{Sitting Crow series, South Dakota}

Samples from Sitting Crow Site $\left(44^{\circ} 1^{\prime} 50^{\prime \prime} \mathrm{N}\right.$ Lat, $99^{\circ} 22^{\prime} 10^{\prime \prime} \mathrm{W}$ Long), Buffalo County, South Dakota. Coll. 1961 by W. E. Buckles, Smithsonian Inst., Lincoln, Nebraska.

\section{I-560. Sitting Crow Site, Mound 3}

$$
\begin{aligned}
& 4400 \pm 250 \\
& 2450 \text { в.C. }
\end{aligned}
$$

Charred bone from a shallow hearth, Feature 7, Mound 3. Comment (R.W.N.) : provides a date for preceramic occupation at site, defined by thin triangular points having slightly convex sides and a concave base. Age is considered minimum (Neuman, 1962).

\section{I-447. Sitting Crow Site, Mound 2}

$2475 \pm 150$ 2525 B.C.

Charcoal from Mound 2, Feature 3. Comment (R.W.N.) : provides date for upper lithic, pre mound occupation (Neuman, 1962). Defined by small triangular points having side notches and a straight base.

\section{I-581. Cheyenne Village Site, South Dakota $775 \pm 125$}

Wood from center post in long-rectangular house (F34) at Cheyenne Village Site $\left(44^{\circ} 46^{\prime} \mathrm{N}\right.$ Lat, $100^{\circ} 43^{\prime} \mathrm{W}$ Long), Stanley County, South Dakota. From same house site as M-840 (650 \pm 200 , Michigan V). Coll. 1955 by W. R. Wedel. Comment (R.W.N.) : represents earliest of three components, with Thomas Riggs focus affinities.

\section{I-561. Site 39CH9, South Dakota}

$$
1425 \pm 110
$$

Charcoal from Feature 21 of mound at Site 39 CH9 $\left(43^{\circ} 3^{\prime} 35^{\prime \prime} \mathrm{N}\right.$ Lat, $98^{\circ} 32^{\prime} 35^{\prime \prime}$ W Long), Charles Mix County, South Dakota. Coll. 1948 by P. L. Cooper. Comment (R.W.N.) : dates mound at this site.

\section{I-614. Site 39SL24, South Dakota}

Wood from post hole fill in F 27, Site 39SL24 $\left(44^{\circ} 47^{\prime} \mathrm{N}\right.$ Lat, $100^{\circ} 42^{\prime}$ W Long), Sully County, South Dakota. F27 is a large circular house structure at a single-component site. It is characterized by circular domiciliary structures clustered around a large ceremonial structure. Pottery is Russell ware (McNutt, 1959). Coll. 1959 by C. H. McNutt, Smithsonian Inst.

\section{I-562. Site 39CH4, South Dakota}

$$
\begin{array}{r}
1230 \\
\text { A.D. } 720
\end{array}
$$

Wood from Mound 1, Site 39CH4 $\left(43^{\circ} 9^{\prime} 8^{\prime \prime}\right.$ N Lat, $98^{\circ} 47^{\prime} 15^{\prime \prime}$ W Long), Charles Mix County, South Dakota. Coll. 1947 by P. L. Cooper of the Smith- 
sonian Inst. Comment (R.W.N.) : provides date for construction of Mound 1 (Cooper, 1949).

\section{I-613. Site 39SL41, South Dakota}

A.D. 1520

$430 \pm 95$

Wood from wall post No. 5 of long-rectangular house at 39SL41, a singlecomponent site of the Thomas Riggs culture $\left(44^{\circ} 34^{\prime} 15^{\prime \prime}\right.$ N Lat, $100^{\circ} 36^{\prime} 20^{\prime \prime}$ W Long), Sully County, South Dakota. Coll. 1958 by C. H. McNutt. Comment (R.W.N.) : dates construction of house.

\section{Boundary Mound series, North Dakota}

Samples from the Boundary Mound Site $\left(45^{\circ} 56^{\prime} 45^{\prime \prime} \mathrm{N}\right.$ Lat, $100^{\circ} 31^{\prime} 30^{\prime \prime}$ W Long), Sioux County, North Dakota. Coll. 1960 and subm. 1962 by R. W. Neuman.

\section{I-499. Boundary Mound Site, Mound 1}

$$
\begin{array}{r}
1540 \pm 160 \\
\text { A.D. } 410
\end{array}
$$

Wood found lying on floor of structure in Mound 1. Mound characterized by a central subfloor tomb, and abundant bison bone remains (Neuman, 1961). Comment (R.W.N.) : samples dates burial with the mound.

I-498. Boundary Mound Site, Mound 2

A.D. 610

Wood from burial pit fill at Mound 2. Comment (R.W.N.) : dates the burials in Mound 2 .

\section{I-414. Boundary Mound Site, Mound 3}

Charcoal from 3.4 ft in Mound 3. Comment (R.W.N.) : dates burials and associated artifacts within the central subfloor chamber of mound. (Wood, 1960; Neuman, 1961).

\section{Effigy Mounds National Monument series, Iowa}

Charcoal samples from burial mounds in Effigy Mounds Natl. Monument (43 $1^{\prime} 45^{\prime \prime} \mathrm{N}$ Lat, $91^{\circ} 11^{\prime} 15^{\prime \prime} \mathrm{W}$ Long), Iowa. Coll. 1961 by the Park Archeologist. (No name available.)

\section{I-441. Marching Bear Mound, No. 1}

$$
1575 \pm 100
$$

Charcoal from area of scattered charcoal and burned earth in heart region of bear-shaped burial mound, $1 \mathrm{ft} 6 \mathrm{in}$. to $2 \mathrm{ft} 10 \mathrm{in}$. below surface. Comment (R.W.N.) : sample provides typical date for Marching Bear mound group.

I-412. Marching Bear Mound, No. 2

$$
\begin{array}{r}
1325 \\
\text { A.D. } 625
\end{array}
$$

Charcoal from area of scattered charcoal and burned earth in heart region of bear-shaped burial mound, 1 to $2 \mathrm{ft}$ deep. Comment (R.W.N.) : date compares with $\mathrm{I}-412,1575 \pm 100$ (this list), and provides typical age for this group of mounds.

\section{I-413. Marching Bear Mound, No. 3}

$$
430 \pm 75
$$

Charcoal from $1.5 \mathrm{ft}$ beneath bottom of treasure hunter's hole at one end of a linear mound considered to be part of the Marching Bear group. 
I-509. Root Site, Kansas

A.D. 975

Charcoal from Pit 3, in floor of House 1, Root Site $\left(38^{\circ} 55^{\prime} 24^{\prime \prime}\right.$ N Lat, $98^{\circ} 29^{\prime} \mathrm{W}$ Long), Lincoln County, Kansas. Site is Smoky Hill aspect in Hell Creek, a tributary of the Saline River (Wedel, 1959). Coll. 1950 by W. R. Wedel.

\section{Medicine Creek Reservoir series, Nebraska}

Samples collected from sites in the Medicine Creek Reservoir area $\left(40^{\circ}\right.$ $22^{\prime} 40^{\prime \prime} \mathrm{N}$ Lat, $100^{\circ} 12^{\prime} 45^{\prime \prime}$ W Long), Frontier County, Nebraska.

\section{I-584. Medicine Creek, Site 25 FT 13}

$$
510 \pm 100
$$

Charcoal from center post 18 to 30 in. deep in Feature 1. 52\% of rim shends are braced. Site is assigned to Upper Republican aspect (Kivett, 1949). Coll. 1948 by M. F. Kivett, Smithsonian Inst.

\section{I-583. Medicine Creek, Site 25 FT 16}

Wood from posthole in House 2, Site 25 FT 16. The site has $60 \%$ braced rims and is assigned to the Upper Republican Aspect (Kivett, 1949). Coll. 1947 by A. T. Hill, Nebraska State Hist. Soc.

\section{I-585. Medicine Creek, Site 25 FT 17}

Charcoal from house floor, Feature 15, at depth of 4 to 6 in. Site has $73 \%$ braced rims, and is assigned to the Upper Republican Aspect (Kivett, 1949). Coll. 1948 by George Metcalf, Smithsonian Inst.

\section{I-496. Kropp Mound, North Dakota $950 \pm 85$

Charcoal from Kropp Mound ( $47^{\circ} 3^{\prime} \mathrm{N}$ Lat, $98^{\circ} 45^{\prime} \mathrm{W}$ Long), Stutsman County, North Dakota. Combined specimens from depth of 6.15 to $7.2 \mathrm{ft}$ Square N220W 150 and 6.55 to $7.15 \mathrm{ft}$ deep in Square N220 W 140. Associated with secondary burials of Feature 13. Tumulus is a large, domed structure with three radiating ridges, two of which have terminal mounds (Wheeler). Coll. 1952 by R. P. Wheeler, Smithsonian Inst., Lincoln, Nebraska.

\section{I-497. Site 32BA1, North Dakota \\ $1860 \pm 150$ A.D. 90}

Wood from log covering central tomb of Mound A, site 32BAl $\left(47^{\circ} 8^{\prime} \mathrm{N}\right.$ Lat, $98^{\circ} 00^{\prime} \mathrm{W}$ Long), Barns County, North Dakota. Construction of tomb characterized by a subfloor, log covering, and bison bone remains (Hewes, 1949). Coll. 1948 by G. W. Hewes, Univ. of North Dakota.

\section{I-644. Buffalo Creek, Wyoming $\quad 2600 \pm 200$}

Charcoal from center section of bone-saturated cultural level 12 in. thick, overlain by $9 \mathrm{ft}$ sterile overburden, at site $30 \mathrm{mi} \mathrm{E}$ of Sheridan $\left(44^{\circ} 46^{\prime} \mathrm{N}\right.$ Lat, $106^{\circ} 58^{\prime}$ W Long), Wyoming, on Buffalo Creek drainage. Coll. and subm. 1962 by R. C. Bentzen, Wyoming Archaeol. Soc., Inc., Sheridan. Comment (R.C.B.) : although artifacts from this site are identical with those recovered 
from the Powers-Yonkee site, they have a $\mathrm{C}^{14}$ age $1850 \pm 325$ yr younger than the Powers-Yonkee (I-410, $4450 \pm 125$, unpub.). This would lengthen considerably the span of McKean culture.

\section{Western United States}

\section{Columbia River series, Oregon}

The following dates are part of the data from a continuing study by the University of the processes of diffusion from the southern interior of the state to the Columbia River (Cressman, 1942, 1956, 1960). The samples were collected by various workers; subm. 1962 by L. S. Cressman. The Round Butte samples are the first firm dates for archaeological material from this part of Oregon.

\section{I-503. John Day Dam Reservoir,}

$6150 \pm 250$ Site 35GM24, Oregon

2200 B.C.

Charcoal from lowest major occupation level of Hobo Cave, Site 35GM24 (45 $43^{\prime} \mathrm{N}$ Lat, $120^{\circ} 33^{\prime} \mathrm{W}$ Long), on left bank of Columbia River ca. $7 \mathrm{mi}$ E of mouth of John Day River, and ca. $25 \mathrm{~m}$ above mean river level in August. Cave fill is separable into three geologic levels based on color and composition. Three side notched points come from below the sample. Coll. 1961 by D. L. Cole. Comment (L.S.C.) : date is evidence that sometime before $6150 \pm 250$ B.P., projectile points characteristic of an early Northern Great Basin type appear on the Columbia (Cressman, 1960).

\section{I-504. John Day Dam Reservoir, $\quad 1400 \pm 150$ Site 35GM9, Oregon \\ A.D. 550}

Charcoal from house (?) planks at John Day Dam Reservoir Site 35GM9, Area 5 ( $45^{\circ} 41^{\prime} 20^{\prime \prime} \mathrm{N}$ Lat, $120^{\circ} 29^{\prime} 42^{\prime \prime} \mathrm{W}$ Long), on left bank Columbia River at Quinton, Oregon. Site covers large area between cliffs and the river and different parts were occupied at different times (Cressman, 1960). This sample comes from portion near river where the surrounding fill was damp. Earlier occupation exists below sample level. Coll. 1961 by D. L. Cole. Comment (L.S.C.) : this sample, with I-504 (this list) give ages for different cultural manifestations in the area. See also Wildcat Canyon site series (M-1119, M-1120, M-1121, M-1122, Michigan VII).

\section{I-500. Round Butte Cave No. 2}

$$
\begin{gathered}
2650 \pm 185 \\
700 \text { в.c. }
\end{gathered}
$$

Charcoal from top of Level I, in Round Butte Cave No. $2\left(44^{\circ} 35^{\prime} \mathrm{N}\right.$ Lat, $121^{\circ} 18^{\prime} \mathrm{W}$ Long), on right bank of Deschutes River slightly above its confluence with the Metolius River, Oregon. Site is ca. 500 yds upriver from site of I-501. Cave has three cultural levels, though they do not differ greatly, numbered I, II, III with I the earliest. While geologic differentiation occurred in the fill, there was no correlation between the cultural and geologic stratification. Coll. 1962 by D. L. Cole. Comment (L.S.C.) : this cave on the right bank of Deschutes River is on side comprising the Columbia Plateau and extending to the Columbia River. It was thus separated from the interior-Columbia River route referred to in I-501 (this list) by rugged canyons ca. $1000 \mathrm{ft}$ deep. 


\section{I-501. Round Butte Cave No. 1}

Charcoal from fire lens approximately halfway down cultural fill in Round Butte Cave No. $1\left(44^{\circ} 35^{\prime} \mathrm{N}\right.$ Lat, $121^{\circ} 18^{\prime} \mathrm{W}$ Long), on left bank Deschutes River, Oregon, ca. $500 \mathrm{yds}$ downstream from confluence with the Metolius River. Fill is separable into two levels geologically, but there was no correlation between varieties of artifacts and the geologic stratigraphy. Coll. 1961 by John Wells. Comment (L.S.C.) : site is in a region relatively unknown archaeologically but is close to the route from the Klamath Lakes and adjacent Northern Great Basin to the Columbia River. Sample age provides a chronological referent for the archaeological manifestations in the area.

\section{Kojohama series, Japan}

\section{Far East}

Charcoal taken from black humus representing lowest level of cultural deposit in floor of pit house at Kojohama Village $\left(42^{\circ} 27^{\prime} \mathrm{N}\right.$ Lat, $141^{\circ} 14^{\prime} \mathrm{E}$ Long), Shiraol County Hokkaido, Japan. Both samples are from same level and date one of the earliest known pottery types in Hokkaido (Oba and Chard, in press). Coll. 1961 by Toshio Oba, Hokkaido Univ., Sapporo, Japan; subm. 1962 by C. S. Chard, Univ. of Wisconsin, Madison.

\section{I-550. Kojohama, undecorated}

Charcoal in association with undecorated, conical base pottery.

\section{I-551. Kojohama, Shell-marked}

Charcoal in association with shell-marked pottery.

General Comment (L.S.C.) : in view of marginal position of Hokkaido in relation to the Tokyo area and the consequent expectable time-lag, these dates lend strong support to the validity of the age of $9450 \pm 400$ (M-769, Michigan V) for the earliest pottery at the Natsushima shell mound near Tokyo. No pottery elsewhere in the world is known to approach such an age.

\section{I-554. Koboro Cave, Japan \\ $375 \pm 90$}

Charcoal from occupational deposit in Koboro Cave $\left(45^{\circ} \mathrm{N}\right.$ Lat, $141^{\circ} \mathrm{E}$ Long), Rebun, Hokkaido, Japan. Sample associated with pottery of Esan type. Coll. 1961 by Toshio Oba; subm. 1962 by C. S. Chard. Comment (C.S.C.) : it was hoped that the sample would date the Post-Jomon Esan pottery. More recent occupations were also identified in the cave; the sample evidently came from a mixed zone as it is far too recent for Post-Jomon.

\section{I-552. Nakazawa Site, Japan \\ $3825 \pm 175$ \\ 1875 в.C.}

Charcoal from interior of pit house assigned to Middle Jomon ceramic

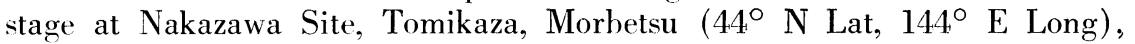
Hokkaido, Japan. Coll. 1961 by Toshio Oba; subm. 1962 by C. S. Chard. Comment C.S.C.) : date is somewhat more recent than expected.

I-555. Tsikibetsu Site, Japan

$920 \pm 100$

1030 в.c.

Charcoal from interior of pit house at Tsikibetsu site, Haboro-cho, To- 
mama ( $44^{\circ} 25^{\prime} \mathrm{N}$ Lat, $141^{\circ} 45^{\prime} \mathrm{E}$ Long), Hokkaido, Japan. House assigned to Satsumon culture and sample was associated with Satsumon pottery. Coll. 1961 by Toshio Oba; subm. 1962 by C. S. Chard. Comment (C.S.C.) : age is close to that expected for Satsumon culture in this area.

\section{I-553. Misato Cave, Japan}

$6800 \pm 225$ 4850 в.C.

Charcoal from Misato Cave $\left(43^{\circ} 40^{\prime} \mathrm{N}\right.$ Lat, $143^{\circ} 50^{\prime} \mathrm{E}$ Long), Kitami City, Hokkaido, Japan. Taken from occupational deposit and associated with pottery. Coll. 1961 by Toshio Oba; subm. 1962 by C. S. Chard. Comment (C.S.C.) : sample dates Early Jomon stage in this area and is close to expected age for this type of pottery.

\section{I-434. Vishnu City, Burma}

$1950 \pm 90$

A.D. 1

Charcoal from structural post in Peikthanomyo (Vishnu City) $\left(20^{\circ} \mathrm{N}\right.$ Lat, $95^{\circ} 23^{\prime} \mathrm{E}$ Long), Kokkogwa Village, Taundwingyi Township, Magwe District, Burma. Site within the old city is debris mound $6 \mathrm{ft}$ above ground level. Sample is from charred wooden post within brick structure. Coll. 1961 by U. Aung Thaw, Archaeol. Society of Burma, Rangon; subm. 1961 by D. W. Overton, Japan Soc., Inc., New York, New York. Comment (U.A.T.) : date is ca. $400 \mathrm{yr}$ earlier than expected in relation with a known site, and ca. $400 \mathrm{yr}$ later than traditional accounts.

\section{EI Inga series, Ecuador}

\section{E. South America}

Soil samples containing powdered charcoal taken from the El Inga site $\left(0^{\circ} 17^{\prime} \mathrm{S}\right.$ Lat, $78^{\circ} 32^{\prime} \mathrm{W}$ Long), in the Andean Highlands near Tumbaco, Ecuador. Samples were to provide date for fluted point complex found at the site and believed to be ca. 8000 to $10,000 \mathrm{yr}$ old on typological grounds and similarities with Fell's Cave type projectile points (Bell, 1960; Mayer-Oakes and Bell, 1960). Coll. and subm. 1961 by R. E. Bell, Univ. of Oklahoma, Norman.

\section{I-557. El Inga, Level 8}

$4000 \pm 190$

2050 в.C.

From stratigraphic block No. 1, Square S 37, Left 1, Level 8, at depth 14 to 16 in. Comment (R.E.B.) : date appears to be too young, but comparative materials are lacking.

\section{I-558. El Enga, Level 6}

$5550 \pm 200$ 2600 в.C.

From Square S 16-Left 2, Level 6 at depth 20 to 22 in. Comment (R.E.B.) : date is consistent with I-557 (this list) in terms of stratigraphy, but also appears too young.

\section{I-637. El Hatillo, Panama}

$415 \pm 90$

A.D. 1535

Charcoal from deep tomb near the Parita River $6 \mathrm{mi} \mathrm{SW}$ of town of Parita, Herrera Province, Panama ( $8^{\circ} \mathrm{N}$ Lat, $80^{\circ} 33^{\prime} \mathrm{W}$ Long). The tomb which yielded the sample was unusually rich in content with a large number and variety of associated artifacts. Coll. 1947 and subm. 1962 by M. W. 
Stirling, Natl. Geog. Soc., Washington, D. C. Comment (M.W.S.) : date confirms archaeologic belief that the El Hatillo culture is later than Cocle and slightly precedes the early 16th century Spanish conquest of Panama (Stirling, 1949).

\section{MISCELLANEOUS SAMPLES}

\section{I-577. Heian figure, Freer Gallery}

$675 \pm 125$

Wood (Torreya rucifera?) chiseled from inside hollow Japanese seated figure 38 in. high now in Freer Gallery of Art, Smithsonian Inst., Washington, D. C. Coll. and subm. 1962 by R. J. Gettens, Freer Gallery of Art. Comment (R.J.G.) : figure dated stylistically as Heian period, 10 to 1lth centuries A.D. $\mathrm{C}^{14}$ date confirms antiquity of the object.

\section{I-476. Seated Buddha figure, Freer Gallery}

$$
\begin{aligned}
& 320 \pm 90 \\
& \text { A.D. } 1630
\end{aligned}
$$

Ivory (elephant?) from Chinese seated Buddha figure $30.8 \mathrm{~cm}$ high now in Freer Gallery of Art, Smithsonian Inst., Washington, D. C. Statuette was ohtained by C. L. Freer in 1916. Coll. and subm. 1961 by R. J. Gettens. Comment (R.J.G.) : figure dated uncertainly on stylistic grounds as Sung Dynasty (A.D. 960 to 1279), but on basis of $\mathrm{C}^{14}$ date is provisionally late Ming (A.D. 1368-1644) or early Ching (A.D. 1644-1912) dynasty.

\section{I-475. Standing Buddha figure, Freer Gallery}

Ivory (elephant?) from a Chinese Buddha figure $45.5 \mathrm{~cm}$ high now in Freer Gallery of Art, Smithsonian Inst., Washington, D. C. Sample chiseled from interior of object. Coll. and subm. 1961 by R. J. Gettens. Comment (R.J.G.) : statue dated stylistically and from inscription as Sung Dynasty (A.D. 960 to 1279). Doubts had arisen in respect to this date and authenticity of the object. $\mathrm{C}^{14}$ date indicates the figure was made from fossil ivory. It is now known that fossil mammoth ivory was abundantly available and widely used for carving over long periods in the Far East. $\mathrm{C}^{14}$ date is interesting in respect to origin of the ivory, but yields no clue as to age of the statue.

\section{I-417. Bat Cave, New Mexico $\quad 5825 \pm 200$

Bat guano from guano and silt fill ca. $1 \mathrm{ft}$ beneath base of flowstone floor of S edge of Bat Cave $\left(32^{\circ} 10^{\prime} 40^{\prime \prime} \mathrm{N}\right.$ Lat, $104^{\circ} 26^{\prime} 10^{\prime \prime} \mathrm{W}$ Long), Carlshad Caverns, New Mexico. Coll. 1959 by Paul Spangle; subm. 1959 by P. T. Hayes. Comment (P.T.H.) : gives maximum age to flowstone floor of Bat Cave and indicates that a large portion of the carbonate decorations in Carlsbad Caverns are quite recent. This date is considerably younger than similar material from heneath flowstone in New Cave, $9 \mathrm{mi}$ SW of Bat Cave (Chicago V).

\section{I-586. Wells Mastodon site, Indiana \\ $12,000 \pm 450$}

Wood from 90 in level in excavation for the Wells $10, \mathbf{0 5 0}$ в.c. 17, T. 30N., R. $2 \mathrm{E}\left(41^{\circ} 4^{\prime}\right.$ N, Lat, $86^{\circ} 15^{\prime}$ W Long), ca. 5 mi W of Rochester, Indiana. Sample is from marl overlain by organic sand and peat, and lies just below level of most of mastodon remains. Coll. and subm. by A. M. Gooding. Comment (A.M.G.) : site is in broad area of valley-train and outwash between 
the Maxinkukee and Packenton moraines. Pollen profile for site suggests mixing of marl by the mastodon, but overlying peat appears not to have been disturbed. A rather rapid change from dominantly coniferous pollen below, to dominantly deciduous pollen above occurs at base of peat. A similar change was dated in a pollen profile near Richmond, Indiana at ca. 11,000 B.P. (Ogden, 1963; Kapp, 1963).

\section{1-587. American Aggregates, Indiana}

Wood from railroad cut at American Aggregates gravel quarry (39 $50^{\prime}$ $30^{\prime \prime} \mathrm{N}$ Lat, $84^{\circ} 49^{\prime} 30^{\prime \prime} \mathrm{W}$ Long), at NE edge of Richmond, Indiana. Taken 6 in. below top of calcareous till. Coll. and subm. by A. M. Gooding. Comment (A.M.G.) : organic silt and till beneath it are believed to be post-Sangamon in age (Gooding, 1963; Kapp, 1963). L-478B, >40,500 (Lamont VII), is from same deposit.

\begin{tabular}{ll} 
Date lists: & \multicolumn{1}{c}{ ReFERENCES } \\
Chicago V & Libby, 1954 \\
Isotopes I & Walton, Trautman and Friend, 1961 \\
Isotopes II & Trautman and Walton, 1962 \\
Lamont V & Olson and Broecker, 1954 \\
Lamont VII & Olson and Broecker, 1961 \\
Michigan IV & Crane and Griffin, 1959 \\
Michigan V & Crane and Griffin, 1960 \\
Michigan VI & Crane and Griffin, 1961 \\
Michigan VII & Crane and Griffin, 1962 \\
Pennsylvania IV & Ralph and Ackerman, 1960 \\
USGS V & Rubin and Alexander, 1960 \\
Yale VI & Stuiver and Deevey, 1961 \\
Yale VII & Stuiver and Deevey, 1962 \\
Yale VIII & Stuiver and Deevey, 1963
\end{tabular}

Bell, R. E., 1962, Evidence of a fluted point tradition in Ecuador: Am. Antiquity, v. 26, no. 1, p. 102-106.

Brown, Jerry, 1962, Soils of the Northern Brooks Range, Alaska: New Brunswick, New Jersey, Rutgers Univ., unpub. thesis.

Capps, S. R., 1916, The Chisana-White River District, Alaska: U. S. Geol. Survey Bull. no. 630,130 p.

Cooper, P. L., 1949, Recent investigations in Fort Randall and Oahe Reservoirs, South Dakota: Am. Antiquity, v. 14 , no. 4, p. $300-310$

Crane, H. R., and Griffin, J. B., 1959, University of Michigan radiocarbon dates IV: Am. Jour. Sci. Radioc. Supp., v. 1, p. 173-198.

- 1960, University of Michigan radiocarbon dates V: Am. Jour. Sci. Radioc. Supp., v. 2, p. 31-48. 125. 1961, University of Michigan radiocarbon dates VI: Radiocarbon, v. 3, p. 105183-204.

Cressman, L. S., et al., 1942, Archaeological researches in the Northern Great Basin: Carnegie Inst. of Washington, pub. 538.

- 1956, Klamath Prehistory: the prehistory of the culture of the Klamath Lake area, Oregon: Amer. Philos. Soc., Trans., v. 46, part 4.

Cressman, et al., 1960, Cultural sequences of the Dalles, Oregon; a contribution to Pacific NW Prehistory; Amer. Philos. Soc., Trans., v. 50, pt. 10.

Douglas, L. A., and Tedrow, J. C. F., 1961, Tundra soils of arctic Alaska: Internatl. Soil Sci. Proc. 7th Cong., v. 4, p. 291-304.

Drysdale, C. W., 1914, Geology of the Thompson River Valley below Kamloops Lake: Canada Geol. Survey, Summ. Rept. 1912, p. 115-150.

Dumond, D. E., 1962, Prehistory in the Naknek Drainage: A preliminary statement in Cressman, L. S., and Dumond, O. R., Research on NW prehistory: Prehistory in the Naknek Drainage, SW Alaska: Univ. of Oregon Dept. of Anthropol., (multilith), p. 7-54. 
Hattersley-Smith, G. F. et al., 1961, The ablation season on Gilman Glacier, northern Ellesmere Island: Internatl. Soc. of Sci. Hydrology, Helsinki, 1960: pub. no. 54, p. $152-168$. Hewes, G. W., 1949, Burial mounds in the Bald Hill area, North Dakota: Amer. Antiquity,
v. 4, no. 4, p. 322-328.

Gooding, A. M., 1963, Illinoian and Wisconsin glaciation, SE Indiana and adajcent areas: in press.

Kapp, R. O., and Gooding, A. M., 1963, Pleistocene vegetational studies in the Whitewater basin, SE Indiana: in press. in pre 1963, A C ${ }^{14}$ dated pollen profile from Sunbeam Prairie, Dark County, Ohio: in press.

Kivett, M. F., 1949, Archaeological investigations in Medicine Creek Reservoir, Nebraska: Am. Antiquity, v. 14, no. 4, p. $278-284$.

Libby, W. F., 1954, Chicago radiocarbon dates V: Science, v. 120, p. 739.

Livingstone, D. A., 1962, Age of Deglaciation in the Ruwenzori Range, Uganda: Nature, v. 194, no. 4831 , p. $859-860$.

Mayer-Oakes, William and Bell, R. E., 1960, Early man site found in Highland Ecuador: Science, v. 131, no. 3416, p. 1805-1806.

McNutt, C. H., 1959, Comments on two Northern Plains pottery wares. Abstract: Nebraska Acad. of Sci. Proc., p. 4.

Miller, C. F., 1958, Russell Cave: new light on stone age life: Natl. Geog. Mag., v. 113, no. 3 , p. $426-437$.

Neuman, R. W., 1961, Excavations of four mound sites in the Oahe Reservoir: Plains Anthropologist, v. 6 , no. 12 , p. $57-58$.

1962, Field Season, 1961: Plains Anthropologist, v. 7, p. 81.

Ogden, J. G. Jr., and Gooding, A. M., 1963, A C ${ }^{14}$ dated pollen profile from Wells Mastodon site, near Richmond, Indiana: as ms.

Olson, E. A., and Broecker, W. S., 1959, Lamont natural radiocarbon measurements V: Am. Jour. Sci. Radioc. Supp., v. 1, p. 1-28.

$141-175$ , Fred, 1962, Glacial geology and geomorphology of the Aortehjorn Area, East Greenland: Arctic, v. 15, no. 1, p. 73-76.

Pewe, T. J., et al., 1953, Multiple glaciation in Alaska: U. S. Geol. Survey Circular 289, p. 13.

Porter, S. C., 1962, Geology of Anaktuvuk Pass, Central Brooks Range, Alaska: Arctic Inst. of N. Am., Final Rept. sub-contract nos. ONR-740 and ONR-264.

Ralph, E. K., and Ackerman, R. E., 1961, University of Pennsylvania radiocarbon dates IV: Radiocarbon, v. 3, p. 4-14.

Rubin, Meyer, and Alexander, Corrinne, 1960, U. S. Geological Survey radiocarbon dates V: Am. Jour. Sci. Radioc. Supp., v. 2, p. 129-185.

Schwartz, D. W., 1961, The Tinsley H. 11 Site: Lexington, Univ. of Kentucky Press, Studies in Anthropol., no. 1.

Sellman, P. V., 1962, Flow and ablation of Gulkana Glacier, Alaska: University of Alaska, unpub. thesis.

Stirling, M. W., 1949, "Exploring the past in Panama": Natl. Geog. Mag., v. 45, p. 373. 399.

Stuiver, Minze, and Deevey, E. S., 1961, Yale natural radiocarbon measurements VI: Radiocarbon, v. 3, p. 126-140.

262. 1962, Yale natural radiocarbon measurements VII: Radiocarbon, v. 4, p. 250 Yale natural radiocarbon measurements

Trautman, M. A., and Walton, Alan, 1962, Isotopes, Inc. radiocarbon measurements II: Radiocarbon, v. 4, p. 35-42.

Walton, Alan, Trautman, M. A., and Friend, J. P., Isotopes, Inc. radiocarbon measurements I: Radiocarbon, v. 3, p. 47-59.

Washburn, A. L., and Stuiver, Minze, 1962, Radiocarbon-dated post-glacial deleveling in northeast Greenland and its implications: Arctic, v. 15, no. 1, p. 66-73.

Wedel, W. R., 1959, An introduction to Kansas archaeology: Bur. of Am. Ethnology Bull. 174

Wheeler, R. P., incomplete ms. on file at office of Missouri Basin Proj., Lincoln, Nebraska. Wood, R. W., 1960, the Boundary mound group: Plains Anthropologist, v. 5, no. 10, p.
71-78. 